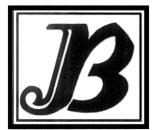

J. Bio-Sci. 29(2): 99-110, 2021 (December)

ISSN 1023-8654

http://www.banglajol.info/index.php/JBS/index

DOI: https://doi.org/10.3329/jbs.v29i2.54959

\title{
INCLUSION OF BIVALVE IN CARP POLYCULTURE PONDS MANAGED BY SMALL INDIGENOUS PEOPLE UNDER BARIND TRACT
}

\author{
T Khatun, RA Raka, MA Islam, MA Hossain, MA Rasel and MRM Mondol* \\ Department of Fisheries, Faculty of Fisheries, University of Rajshahi, Rajshahi-6205, Bangladesh
}

\begin{abstract}
The present experiment was carried out in the household ponds (0.04 to 0.08 ha in area with 1.3 to 2.4 $m$ in depth) of small indigenous people at Barind Tract region, northwest Bangladesh during September, 2017 to June, 2018 to know the growth performance of bivalve with carp. Two different treatments with 3 replicates were used, in treatment one $\left(\mathrm{T}_{1}\right)$ only the carp polyculture was performed and in treatment two $\left(T_{2}\right)$ carp and bivalve polyculture was performed. Good quality of carp fingerlings (Labeo rohita, Gibelion catla, Cirrhinus cirrhousus, Hypophthalmichthys molitrix and Ctenopharyngodon idella) and freshwater bivalve (Lamellidens marginalis) seeds were stocked in the ponds. Stocking density and size of the seeds were similar for all of the study ponds. During the experiment there were no significant differences was observed in growth performance of the fishes between the two different treatments $(p<0.05)$. The weight gain was recorded for $L$. rohita $420.31 \mathrm{~g}$ in $T_{1}$ and $436.25 \mathrm{~g}$ in $T_{2}$, for $G$. catla $237.01 \mathrm{~g}$ in $T_{1}$ and $329.66 \mathrm{~g}$ in $\mathrm{T}_{2}$, for $C$. cirrhosus $263.53 \mathrm{~g}$ in $\mathrm{T}_{1}$ and $301.74 \mathrm{~g}$ in $\mathrm{T}_{2}$, for $\mathrm{H}$. molitrix $559.6 \mathrm{~g}$ in $\mathrm{T}_{1}$ and 593.57 $\mathrm{g}$ in $\mathrm{T}_{2}$, for $C$. idella $510.11 \mathrm{~g}$ in $\mathrm{T}_{1}$ and $619.57 \mathrm{~g}$ in $\mathrm{T}_{2}$. The weight gain of $L$. marginalis was $12.3 \mathrm{~g}$ in $\mathrm{T}_{2}$. During this experiment the production of carp was recorded $2524.5 \mathrm{~kg} / \mathrm{ha}$ in $\mathrm{T}_{1}$ and $2618.2 \mathrm{~kg} / \mathrm{ha}$ in $\mathrm{T}_{2}$ and the bivalve production was $1284.4 \mathrm{~kg} / \mathrm{ha}$ in $\mathrm{T}_{2}$. This study is the first report on growth performance of bivalve with carp in the Barind Tract region of northwest Bangladesh. The result of this study will be helpful for the development of bivalve aquaculture in this climatically vulnerable region.
\end{abstract}

Key words: Barind Tract, Bivalve, Carp, Indigenous people, Polyculture

\section{Introduction}

Aquaculture is the farming and husbandry of aquatic organisms under controlled or semi-controlled conditions. With the increase in human population and diminished natural fisheries resources, aquaculture is rapidly gaining importance. Pond aquaculture is growing fast in many resource-constrained Asian countries (Hossain et al. 2020). In order to maintain the present per capita fish demand, further growth of aquaculture production is needed as the supply through capture fisheries cannot grow any more. Aquaculture has turned to a promising economic sector in Bangladesh. Aquaculture contributes over $50 \%$ of the total fish production of Bangladesh (DoF 2017). Advancement of technologies leads to aquaculture as a more profitable approach day by day.

Apart from the technology, recent climate change aspect makes some region more vulnerable than other parts of the country. Barind Tract is one of the climatically vulnerable zones in northwest Bangladesh, characterized by red or yellow clay soil, limited rainfall and lack of water sources in the dry season. Barind Tract is potential for aquaculture development in the homestead ponds by the poor indigenous people (Arook et al. 2016). In recent years, small indigenous people are facing critical challenges of poverty, nutrition and

*Author for correspondence: mostafiz_bau@yahoo.com 
employment (Samad 2006). Bivalves are one of the most favorite food items to the small indigenous people, they usually collect the bivalves from different water bodies and consumed as food. In recent years the availability of the bivalves in the water resources rapidly declined due to over harvesting, habitat degradation, pollution etc. So, there is a great potential of inclusion of bivalve in the carp culture ponds of the small indigenous people in the Barind Tract region.

Worldwide, there are many research works have been reported on carp polyculture (Rahman et al. 2006). In southern India, fresh water bivalve's aquaculture is initiated for human consumption (Chakraborty et al. 2008). Still to date there is no research work on bivalve aquaculture, especially in the Barid Tract region of the northwest Bangladesh. Therefore, the present experiment investigated the growth performance of bivalve in carp polyculture ponds managed by small indigenous people at Barind Tract, northwest Bangladesh. The culture of bivalves with carps could offer the best possibility of nutritional enhancement of the small indigenous people in the climatically vulnerable Barind Tract region. The specific objectives of this experiment were i) to evaluate the water quality parameters of the study ponds; ii) to evaluate the growth performance of bivalve and carps; and iii) to recommend the suitability of carp-bivalve polyculture in the ponds at Barind Tract region.

\section{Materials and Methods}

\section{Study area and pond selection}

The present experiment was conducted in the homestead ponds at Jugisho village of Tanore upazila under Rajshahi district in northwest Bangladesh for a period of 10 months during September 2017 to June 2018 (Fig. 1). The geographical location of the study site was in between $24^{\circ} 34^{\prime}$ and $24^{\circ} 36^{\prime}$ north and in between $88^{\circ} 33^{\prime}$ and $88^{\circ} 35^{\prime}$ east. Historically the Tanore upazila is one of the important areas in the northwest region, where small indigenous people (Swantal) are living and contributing to the socio-economic development of this region. The experimental ponds were selected from the indigenous people community having 0.04 to 0.08 ha in area with 1.3 to $2.4 \mathrm{~m}$ in depth. All the selected ponds were rain-fed, well exposed to prevailing sunlight and without inlet or outlet.

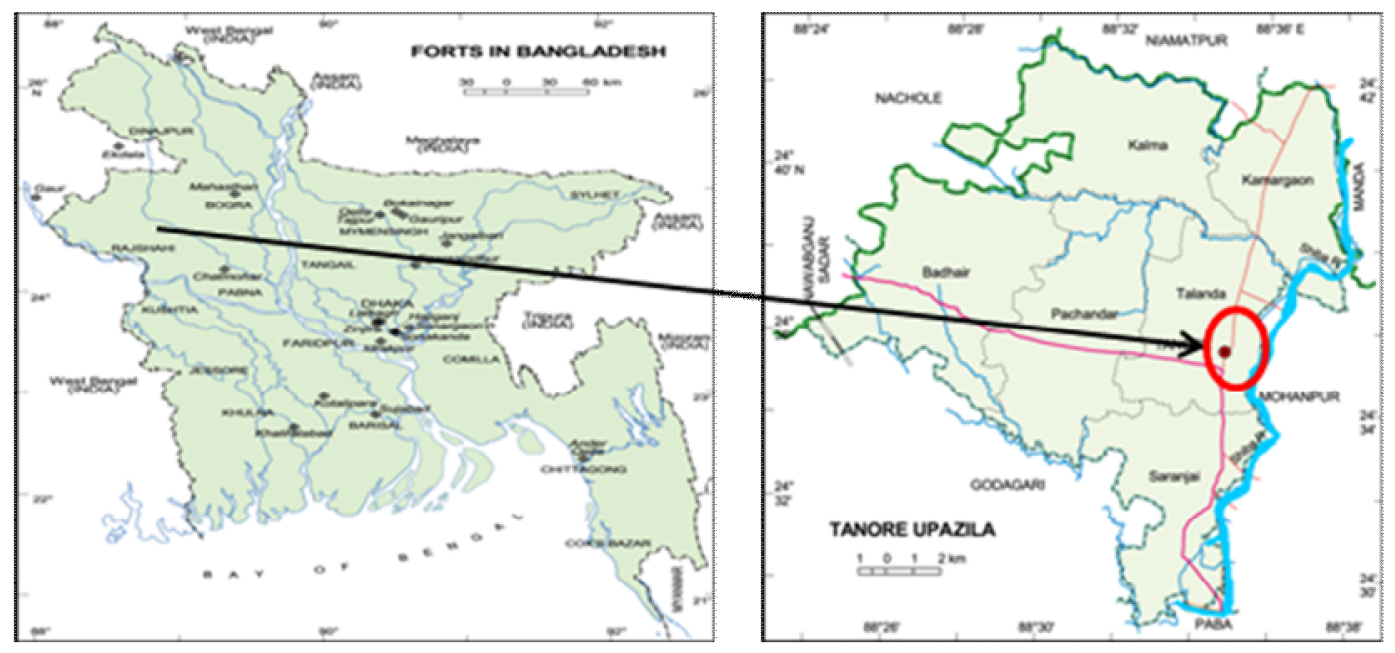

Fig. 1: Location of study area at Tanore upazila under Rajshahi district, Northwest Bangladesh. 


\section{Experimental ponds}

The experiment included two treatments with three replicates each and the treatments were selected randomly. In this experiment, only the carps were stocked in the ponds of $T_{1}$ and carp with bivalve Lamellidens marginalis were stocked in the ponds of $T_{2}$. Stocking density was same for carp in both of the treatments.

\section{Pond preparation}

The pond banks and embankments were raised and repaired properly in broken places. Aquatic vegetation was removed completely from the ponds manually. All predatory and unwanted fishes were removed from the experimental ponds by repeated netting.

\section{Liming}

Ponds were prepared properly with lime (494 kg/ha). Before applying lime, it was mixed with water carefully and kept exposed for a while to avoid heat generation and finally spread over the surface of the mud in a soluble form. After 7 days of liming, ponds were filled with supplied ground water.

\section{Fertilization}

Fertilization was done in the ponds with Urea and TSP (triple super phosphate) at a proportion of 1:1 to stimulate the productivity of the ponds and applied 7 days before stocking with the preferred type of fishes as basal fertilization. The initial basal fertilization dose was urea $(123 \mathrm{~kg} / \mathrm{ha})$ and TSP (123 kg/ha). TSP was applied into the ponds, after dissolving in plastic bucket 10 to $12 \mathrm{~h}$ before fertilization.

\section{Stocking}

Good quality carp seeds were collected from a reputed fish fry trader of Amnura, Chapainawabganj and transported in aluminum container with aeration to minimize the mortality. Bivalves (L. marginalis) seed were collected from the research pond of Fisheries Department of Rajshahi University. The initial length and weight of carp fingerlings and bivalves seed were measured and stocking was done early in the morning (at 7.0 AM) after 7 days of basal fertilization (Table 1).

Table 1. Species composition, initial length, weight and stocking density in each treatment.

\begin{tabular}{lcccc}
\hline & Initial length & Initial weight & \multicolumn{2}{c}{$\begin{array}{c}\text { Stocking density } \\
\text { (piece/ha) }\end{array}$} \\
\cline { 4 - 5 } & $(\mathrm{cm})$ & $(\mathrm{g})$ & $\mathrm{T}_{1}$ & $\mathrm{~T}_{2}$ \\
\hline Labeo rohita & $19.9 \pm 1.2$ & $101.8 \pm 13.6$ & 1250 & 1250 \\
Gibelion catla & $27.8 \pm 2.3$ & $263.8 \pm 47.4$ & 500 & 500 \\
Cirrhinus cirrhosus & $21.7 \pm 0.4$ & $138.9 \pm 2.8$ & 1250 & 1250 \\
Hypophthalmichthys molitrix & $16.0 \pm 1.0$ & $40.1 \pm 8.6$ & 1500 & 1500 \\
Ctenopharyngodon idella & $16.3 \pm 4.1$ & $58.9 \pm 54.0$ & 500 & 500 \\
Lamellidens marginalis & $4.3 \pm 0.5$ & $14.1 \pm 1.7$ & - & 50000 \\
\hline
\end{tabular}




\section{Post stocking management}

Immediately after stocking, daily fertilization was followed as Urea $6.25 \mathrm{~kg} / \mathrm{ha}$, TSP $6.25 \mathrm{~kg} / \mathrm{ha}$. The TSP was dissolved in water and then mixed with urea and spread this water surface of the ponds. Commercial fish feed was used daily at the rate of 3-4\% of fish body weight.

\section{Fish growth monitoring}

To determine the growth performance of the fish and bivalve, monthly length and weight were measured. The total length of fish species and bivalve was recorded separately to the nearest centimeter scale. The weight of both carp and bivalve was taken by a digital electric balance. Fishes were sampled monthly using a seine net and bivalves were sampled by hand picking to determine the growth and to adjust the feed ration. Growth and production of fishes was calculated after Brett and Groves (1979) as follows:

Final weight $(\mathrm{g})=$ Weight of fish at harvest $(\mathrm{g})$

Weight gain $(\mathrm{g})=$ Mean final weight $(\mathrm{g})$ - Mean initial weight $(\mathrm{g})$

Specific growth rate $\left(S G R, \% b^{-1} d^{-1}\right)=\left[L_{n}\right.$ (final weight) $-L_{n}$ (initial weight) $] /$ culture period (days $) \times 100$

Fish yield $(\mathrm{kg} / \mathrm{ha} /$ culture period $)=$ Fish biomass at harvest - Fish biomass at stock.

\section{Monitoring of water quality parameters}

Some important water quality parameters of the experimental ponds such as water temperature, transparency, dissolved oxygen (DO), $\mathrm{pH}$, alkalinity and free carbon dioxide $\left(\mathrm{CO}_{2}\right)$ were monitored monthly between 10:00 AM to 11:00 AM for the present study. Water temperature was recorded with the help of a Celsius thermometer at 20 to $30 \mathrm{~cm}$ depth of water. Transparency was measured by a Secchi disk. DO, pH, alkalinity and free $\mathrm{CO}_{2}$ were determined using $\mathrm{HACH}$ kit (FF-2, USA).

\section{Data analysis}

Data on water quality parameters, fish growth and yield of polyculture under two different treatments was subjected to paired t-test using computer software SPSS (version-20.0) at $p<0.05$ level of significance.

\section{Results}

\section{Growth performance of fish and bivalve}

In the present experiment, there were no significant differences was observed in growth performance both length and weight of $L$. rohita, G. catla, C. cirrhosus, $H$. molitrix and $C$. idella between two different treatments $(p<0.05)$. Weight increment of the fishes was slower during September to December 2017 and a rapid weight increment was observed during January and June 2018 (Fig. 2-6). However, growth of the fishes was higher in $\mathrm{T}_{2}$ in compare with $\mathrm{T}_{1}$ (Fig. 2-6).

\section{Length gain}

The length gain for $L$. rohita was recorded $9.95 \mathrm{~cm}$ in $T_{1}$ and $13.5 \mathrm{~cm}$ in $T_{2}$. In case of $G$. catla length gain was $4.69 \mathrm{~cm}$ in $T_{1}$ and $7.05 \mathrm{~cm}$ in $T_{2}$, for $C$. cirrhosus $7.04 \mathrm{~cm}$ in $T_{1}$ and $7.17 \mathrm{~cm}$ in $T_{2}$, for $H$. molitrix 15.71 $\mathrm{cm}$ in $T_{1}$ and $20.64 \mathrm{~cm}$ in $T_{2}$, for $C$. idella the length gain was $17.54 \mathrm{~cm}$ in $T_{1}$ and $18.37 \mathrm{~cm}$ in $T_{2}$. During the study, the higher length gain $H$. molitrix and lower length gain was recorded for $G$. catla. The length gain of $L$. marginalis was $1.73 \mathrm{~cm}$ in $\mathrm{T}_{2}$ (Table 2). 


\section{Weight gain}

The weight gain for $L$. rohita was recorded $420.31 \mathrm{~g}$ in $T_{1}$ and $436.25 \mathrm{~g}$ in $T_{2}$. In case of $G$. catla weight gain was $237.01 \mathrm{~g}$ in $\mathrm{T}_{1}$ and $329.66 \mathrm{~g}$ in $\mathrm{T}_{2}$, for $\mathrm{C}$. cirrhosus $263.53 \mathrm{~g}$ in $\mathrm{T}_{1}$ and $301.74 \mathrm{~g}$ in $\mathrm{T}_{2}$, for $H$. molitrix 559.6 $\mathrm{g}$ in $\mathrm{T}_{1}$ and $593.57 \mathrm{~g}$ in $\mathrm{T}_{2}$, for $C$. idella the weight gain was $510.11 \mathrm{~g}$ in $\mathrm{T}_{1}$ and $619.57 \mathrm{~g}$ in $\mathrm{T}_{2}$. The weight gain of $L$. marginalis was $12.3 \mathrm{~g}$ in $\mathrm{T}_{2}$ (Table 2).

\section{Specific growth rate (SGR \%)}

The specific growth rate SGR (\%) of $L$. rohita was obtained as $0.54 \%, 0.55 \%$, in $T_{1}$, and $T_{2}$ respectively. In case of $G$. catla it was $0.21 \%$, and $0.27 \%$, in $\mathrm{T}_{1}$ and $\mathrm{T}_{2}$ respectively. In C. cirrhosus SGR (\%) was observed as $0.35 \%$, and $0.38 \%$, in $T_{1}$ and $T_{2}$ respectively. For $H$. molitrix SGR (\%) was $0.90 \%$ and $0.91 \%$ in $T_{1}$ and $T_{2}$ respectively. For $C$. idella SGR (\%) was $0.75 \%$, and $0.81 \%$ in $\mathrm{T}_{1}$ and $\mathrm{T}_{2}$ respectively. The specific growth rate of L. marginalis was $5.23 \%$ in $\mathrm{T}_{2}$ (Table 2 ).

\section{Fish and bivalve production}

In the present experiment, the production of carp fish was recorded $2524.5 \mathrm{~kg} / \mathrm{ha}$ in $\mathrm{T}_{1}$ and $2618.2 \mathrm{~kg} / \mathrm{ha}$ in $\mathrm{T}_{2}$ (Table 2). The production of bivalve was obtained $1284.4 \mathrm{~kg} / \mathrm{ha}$ in $\mathrm{T}_{2}$ (Table 2).

Table 2. Final weight, length gain, weight gain, specific growth rate (SGR\%) and production of fish and bivalve during the experiment.

\begin{tabular}{|c|c|c|c|c|c|c|}
\hline Treatments & Species & Final weight $(\mathrm{g})$ & $\begin{array}{c}\text { Length } \\
\text { gain }(\mathrm{cm})\end{array}$ & $\begin{array}{l}\text { Weight } \\
\text { gain }(\mathrm{g})\end{array}$ & SGR (\%) & $\begin{array}{c}\text { Production } \\
\mathrm{Kg} / \mathrm{ha}\end{array}$ \\
\hline \multirow{5}{*}{$\mathrm{T}_{1}$} & L. rohita & $518.2 \pm 53.24$ & 9.95 & 420.31 & 0.54 & \multirow{5}{*}{2524.5} \\
\hline & G. catla & $500.85 \pm 35.81$ & 4.69 & 237.01 & 0.21 & \\
\hline & C. cirrhosus & $402.5 \pm 42.41$ & 7.04 & 263.53 & 0.35 & \\
\hline & H. molitrix & $602.25 \pm 27.52$ & 15.71 & 559.80 & 0.90 & \\
\hline & C. idella & $569.1 \pm 25.85$ & 17.54 & 510.11 & 0.75 & \\
\hline \multirow{6}{*}{$\mathrm{T}_{2}$} & L. rohita & $538.2 \pm 46.13$ & 13.50 & 423.31 & 0.55 & \multirow{5}{*}{2618.2} \\
\hline & G. catla & $588.29 \pm 48.59$ & 7.05 & 324.45 & 0.27 & \\
\hline & C. cirrhosus & $443.08 \pm 65.87$ & 7.17 & 304.11 & 0.38 & \\
\hline & H. molitrix & $633.25 \pm 52.01$ & 20.64 & 602.15 & 0.91 & \\
\hline & C. idella & $681.78 \pm 63.9$ & 18.37 & 624.45 & 0.81 & \\
\hline & L. marginalis & $26.5 \pm 9.2$ & 1.73 & 12.30 & 5.23 & 1284.4 \\
\hline
\end{tabular}

SGR = Specific growth rate, $\mathrm{T}=$ Treatment. 


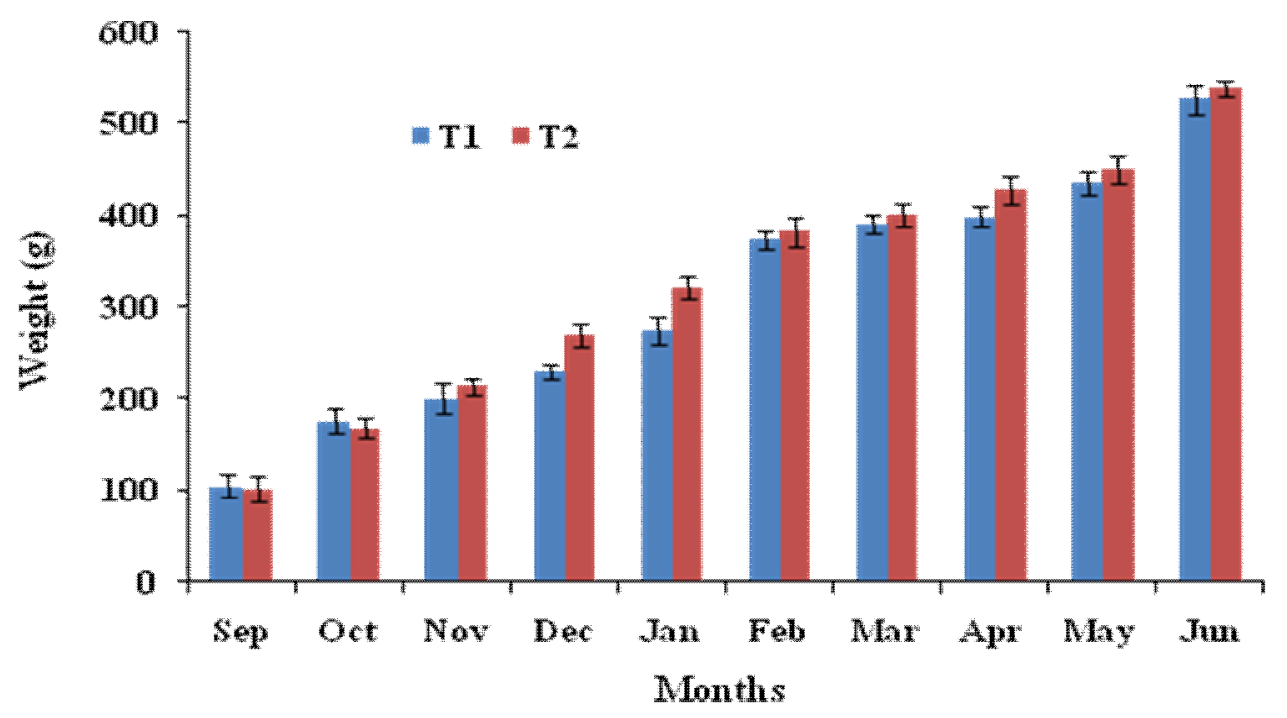

Fig. 2: Monthly weight increment (Mean $\pm S D$ ) of $L$. rohita in $T_{1}$ and $T_{2}$.

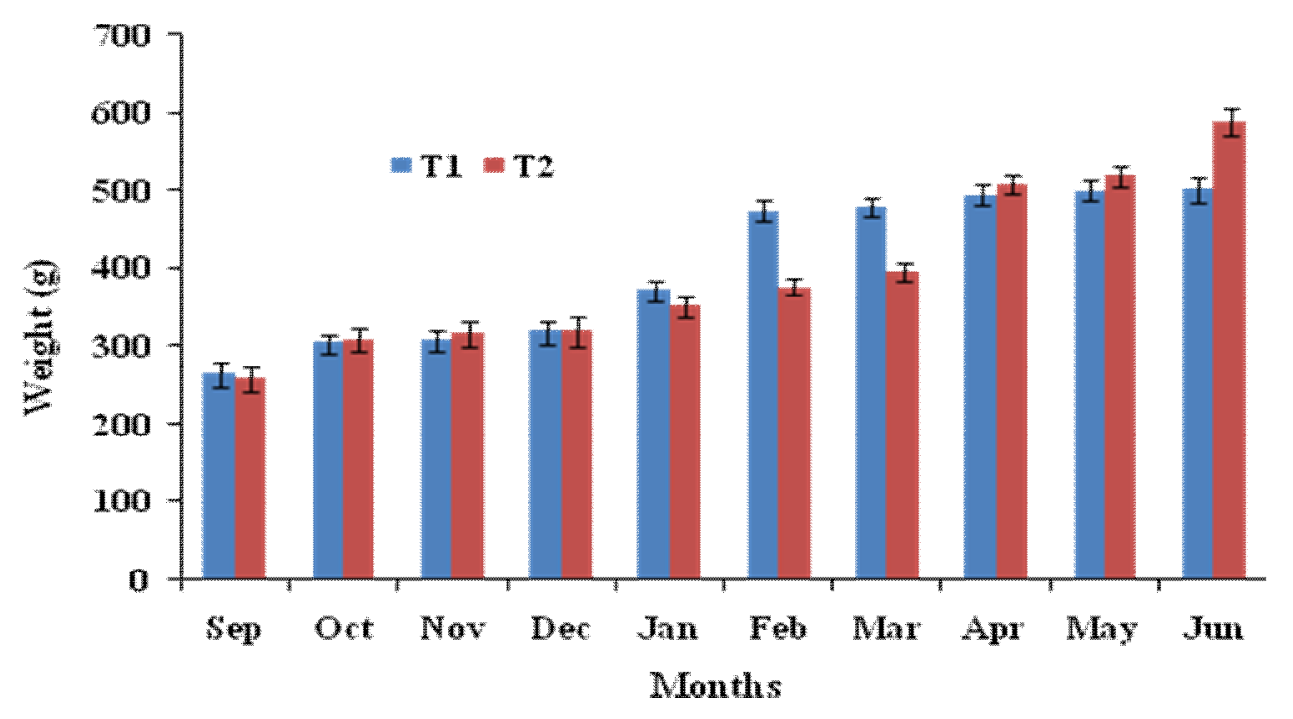

Fig. 3: Monthly weight increment (Mean $\pm S D$ ) of $G$. catla in $T_{1}$ and $T_{2}$. 


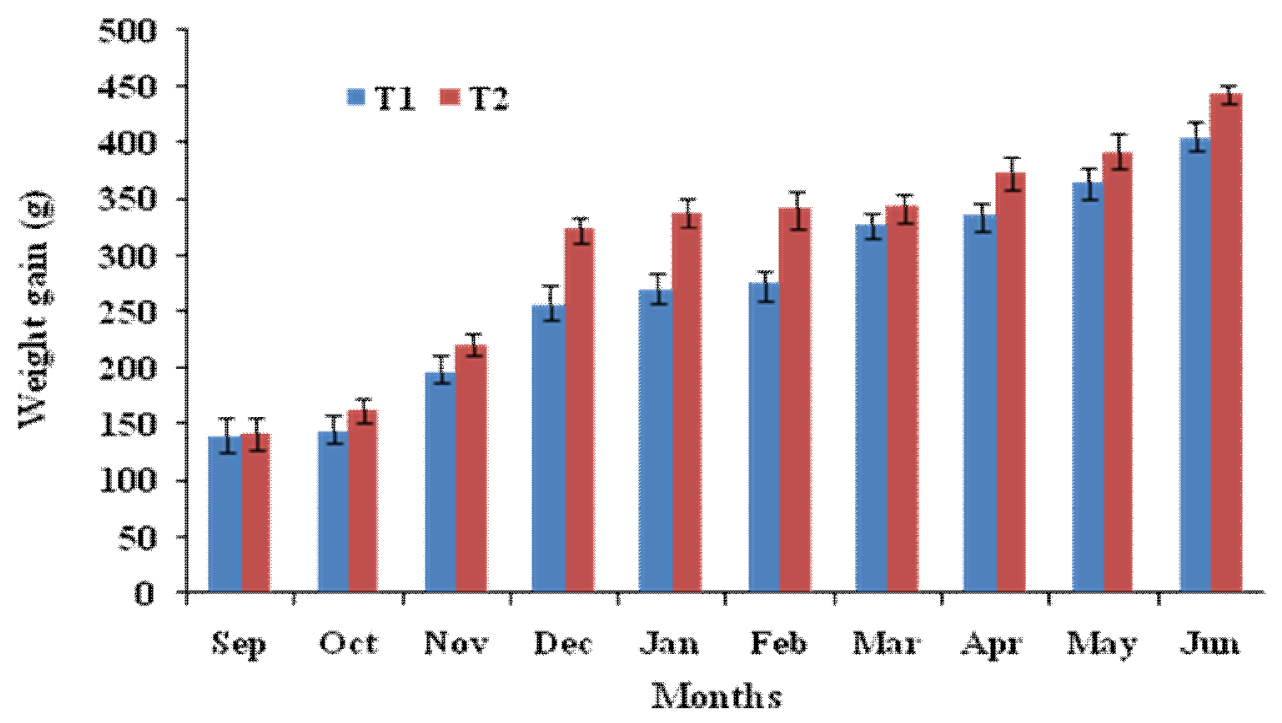

Fig. 4: Monthly weight increment (Mean $\pm S D$ ) of $C$. chirrhosus in $T_{1}$ and $T_{2}$.

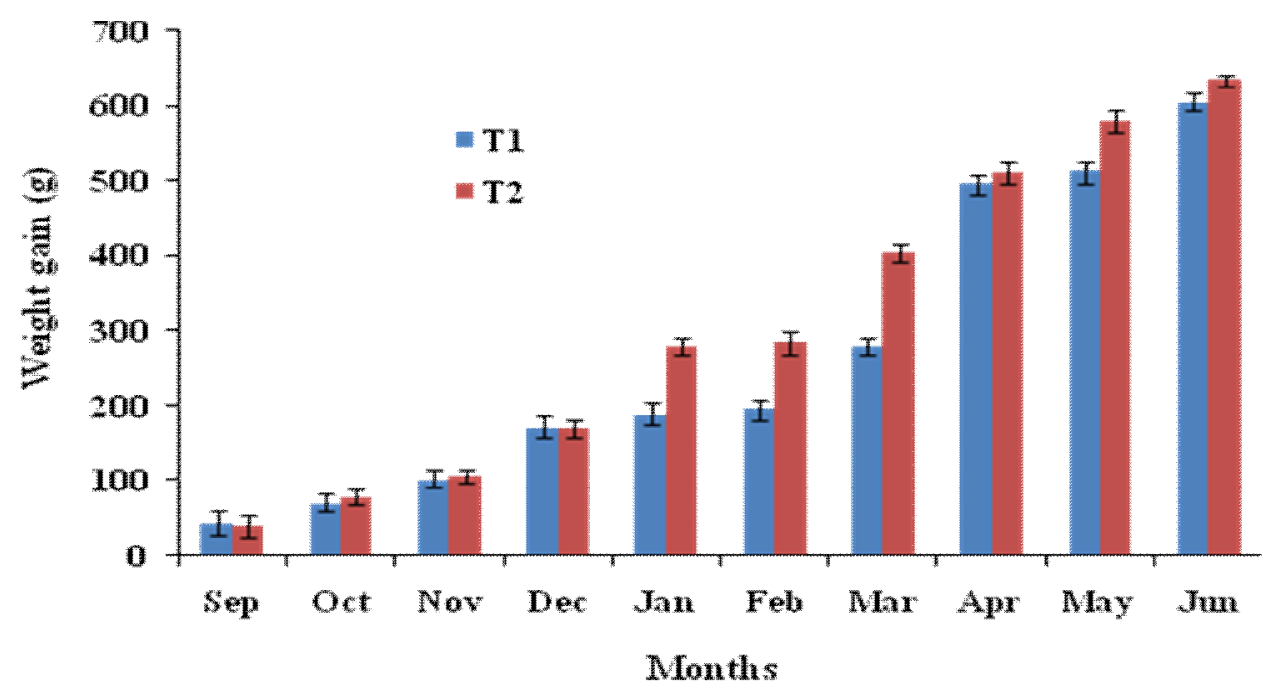

Fig. 5: Monthly weight increment (Mean $\pm S D$ ) of $H$. molitrix in $T_{1}$ and $T_{2}$. 


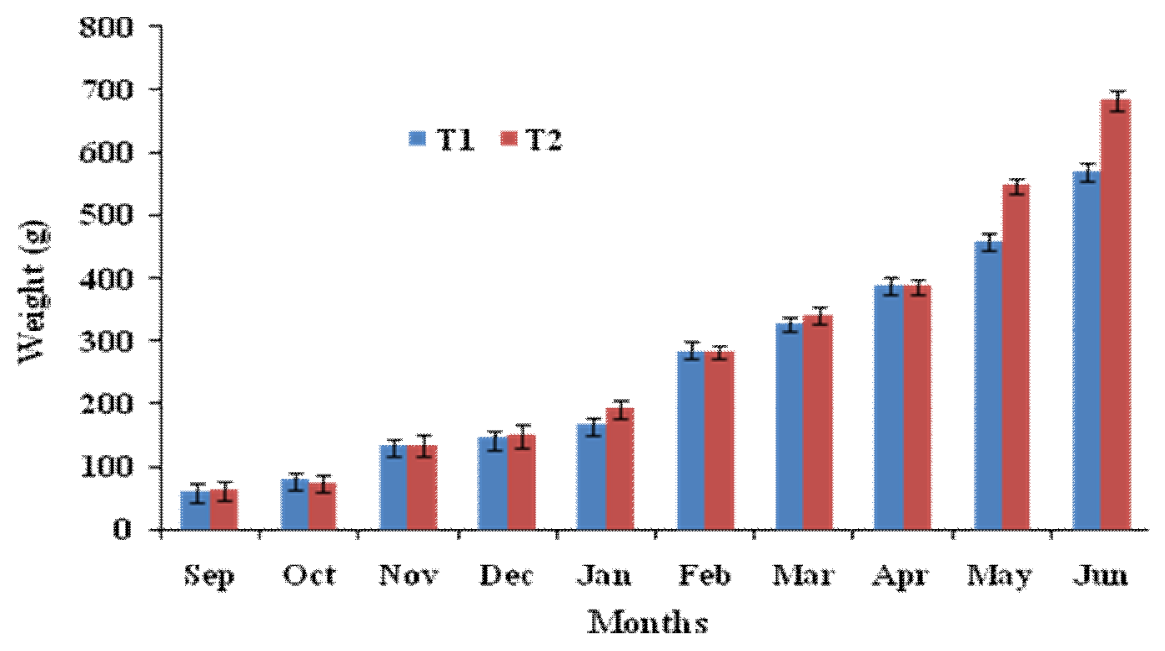

Fig. 6: Monthly weight increment (Mean $\pm S D$ ) of $C$. idella in $T_{1}$ and $T_{2}$.

\section{Water quality parameters}

The result of water quality parameters temperature, transparency, dissolved oxygen, $\mathrm{pH}, \mathrm{CO}_{2}$ and alkalinity are shown in Table 3. During this experiment, the water temperature ranged between $19.2-30.4^{\circ} \mathrm{C}$ in $\mathrm{T}_{1}$ and $18.3-31.0^{\circ} \mathrm{C}$ in $T_{2}$, transparency $23.0-31.0 \mathrm{~cm}$ in $T_{1}$ and $22.0-32.0 \mathrm{~cm}$ in $\mathrm{T}_{2}, \mathrm{DO} 4.5-7.2 \mathrm{mg} / \mathrm{l}$ in $\mathrm{T}_{1}$ and $5.4-7.2 \mathrm{mg} / \mathrm{lin} \mathrm{T}_{2}, \mathrm{CO}_{2} 5.4-8.5 \mathrm{mg} / \mathrm{l}$ in $\mathrm{T}_{1}$ and $5.0-8.7 \mathrm{mg} / \mathrm{lin} \mathrm{T}_{2}$, alkalinity $48.0-85.0 \mathrm{mg} / \mathrm{l}$ in $\mathrm{T}_{1} 48.0$ 75.0 in $\mathrm{T}_{2}$ and $\mathrm{pH} 6.8-7.6$ in $\mathrm{T}_{1}$ and $6.8-7.8$ in $\mathrm{T}_{2}$. The water quality parameters of this experiment were within the suitable range did not differ significantly between the treatments $(p<0.05$, Table 3$)$.

Table 3. Monthly variations of water quality parameters in $T_{1}$ and $T_{2}$

\begin{tabular}{cccccccccccc}
\hline Parameters & Treatments & Sep & Oct & Nov & Dec & Jan & Feb & Mar & Apr & May & Jun \\
\hline Temperature & $\mathrm{T}_{1}$ & 29.0 & 25.6 & 26.2 & 21 & 19.2 & 22.5 & 26 & 26.8 & 28.5 & 30.4 \\
$\left({ }^{\circ} \mathrm{C}\right)$ & $\mathrm{T}_{2}$ & 28.0 & 25.9 & 26.5 & 21.8 & 18.3 & 22 & 25.8 & 26.5 & 28.8 & 31 \\
\hline Transparency & $\mathrm{T}_{1}$ & 27.5 & 25 & 26.0 & 23 & 24.4 & 24.8 & 25 & 26.8 & 27 & 31 \\
$(\mathrm{~cm})$ & $\mathrm{T}_{2}$ & 28.0 & 25.5 & 23.0 & 22 & 24.5 & 23.2 & 24 & 27 & 29 & 32 \\
\hline $\mathrm{DO}$ & $\mathrm{T}_{1}$ & 5.15 & 4.5 & 5.9 & 6.3 & 6.8 & 5.6 & 6.7 & 7.2 & 6.9 & 7.1 \\
$(\mathrm{mg} / \mathrm{l})$ & $\mathrm{T}_{2}$ & 6.2 & 5.8 & 6.4 & 6.9 & 7.2 & 6.5 & 5.4 & 6.8 & 6.4 & 6.9 \\
\hline $\mathrm{CO}_{2}$ & $\mathrm{~T}_{1}$ & 8.5 & 6.4 & 5.4 & 5.8 & 7.6 & 7.5 & 6.8 & 5.8 & 6.6 & 6.8 \\
$(\mathrm{mg} / \mathrm{l})$ & $\mathrm{T}_{2}$ & 7.6 & 8.7 & 5.9 & 5 & 6.4 & 7.2 & 5.8 & 6.5 & 5.4 & 8.9 \\
\hline Alkalinity & $\mathrm{T}_{1}$ & 52 & 64 & 48 & 58 & 69 & 55 & 52 & 60 & 85 & 75 \\
$(\mathrm{mg} / \mathrm{l})$ & $\mathrm{T}_{2}$ & 55 & 48 & 45 & 58 & 65 & 65 & 75 & 68 & 56 & 62 \\
\hline $\mathrm{pH}$ & $\mathrm{T}_{1}$ & 7.2 & 7.6 & 6.8 & 7.1 & 7.3 & 7.5 & 6.9 & 7.8 & 7.2 & 7.6 \\
& $\mathrm{~T}_{2}$ & 7.5 & 7.3 & 7.3 & 7.5 & 6.8 & 7.3 & 6.8 & 7.5 & 7.5 & 7.8 \\
\hline
\end{tabular}




\section{Discussion}

In this experiment growth rate of the fishes was lower during September and December and a dramatic growth performance was observed from January to June. During this experiment, length gain was the highest for $C$. idella in $T_{1}$ and $H$. molitrix in $T_{2}$ and lowest length gain for $G$. catla in both of the treatments. On the other hand, the highest weight gain was recorded for $C$. idella in both of the treatments and lowest weight gained for $G$. catla in $T_{1}$ and $C$. cirrhosus in $T_{2}$. During this experiment, growth performance of the fishes was not significantly different between the treatments $(p>0.05)$, while a higher growth was recorded for all the fishes in $T_{2}$. The better growth performance of the fishes recorded in the $T_{2}$ could be linked with the inclusion of the bivalves in the ponds. Freshwater bivalves are an important component of many healthy river and pond ecosystem. In addition, freshwater bivalves often are used by various agencies to monitor environmental quality, including trends of chemical contamination (Rosenberg and Resh 1993).

\section{Fish production}

Final weight, weight gain and SGR (\%) of the fishes in this experiment were more or less similar with the findings of Kabir et al. (2017) and Talukder et al. (2018) whereas they followed irregular stocking combination and smaller initial stocking size for fishes. In the present experiment the fish production was $2524.5 \mathrm{~kg} / \mathrm{ha}$ in $\mathrm{T}_{1}$ and $2618.2 \mathrm{~kg} / \mathrm{ha}$ in $\mathrm{T}_{2}$ and bivalve production was obtained $1284.4 \mathrm{~kg} / \mathrm{ha}$ in $\mathrm{T}_{2}$ (Table 2). Haque (2010) reported the production of Indian major carp ranging from $2618.85 \pm 57.5$ to $2747.47 \pm 116.47 \mathrm{~kg} / \mathrm{ha} / \mathrm{year}$, which is similar with the production of the present experiment. The finding of this study are more or less similar to the findings of Lakshman et al. (1971), they reported similar production for Indian major carp and exotic carp by feeding with supplementary feed containing rice bran and mustard oil cake in composite

culture. A study conducted by Talukder et al. (2017) in carp polyculture ponds under drought prone Barind area had reported a fish yield ranging from $1411.29 \pm 25.19$ to $3693.23 \pm 69.37 \mathrm{~kg} / \mathrm{ha} / 6$ months which was also comparable with the findings of the present study. Hossain et al. (2020) from the same geographic area reported the production of carps $3451.50 \pm 32.62$ to $4192.54 \pm 79.37 \mathrm{~kg} / \mathrm{ha} / 6$ months. They used carp fattening technology and stocked larger size fish species in their culture ponds.

\section{Water quality parameters}

Water quality is one of the most important factors in ensuring a healthy fish production. Water quality in aquatic environment considerably affects the growth and reproduction of fishes. If the water quality is beyond tolerable limits, fish health is adversely affected. The primary productivity of water body is dependent on physical and chemical factors of water in relation to the other environmental factors (Rahman et al. 1982). Aquaculture depends almost completely on the water quality. The suitable water quality parameters are prerequisite for a healthy aquatic environment and for the production of sufficient fish food organisms. In the present experiment there was significant differences was observed in water quality parameters between the two different treatments $(p<0.05)$. The water temperature of the study ponds were found to vary from 18.3$31.0^{\circ} \mathrm{C}$. The highest temperature was recorded in the month of June and the lowest temperature was recorded in the month of January. A more or less similar temperature was recorded by Mollah and Haque (1978) who recorded the water temperature ranges from 26.0 to $32.44^{\circ} \mathrm{C}$ in ponds at Bangladesh Agricultural University Campus, Mymensingh. Alam et al. (2002) recorded minimum surface water temperature $\left(16^{\circ} \mathrm{C}\right)$ during winter and maximum $\left(33^{\circ} \mathrm{C}\right)$ in summer. The fluctuation of water temperature might be due to solar radiation or rain. Bhatnagar and Devi (2013) suggested 20 to $30^{\circ} \mathrm{C}$ water temperature is suitable for carp polyculture ponds which is also more or less similar with the findings of the present study. During the study period the water transparency varied from $22.0-32.0 \mathrm{~cm}$, which was more or less similar to Wahab et al. (1995) who suggested that the transparency of productive water should be $40 \mathrm{~cm}$ or less. Boyd (1998) 
recommended a transparency between $30-45 \mathrm{~cm}$ as good for fish culture. Dissolved oxygen is another important water quality parameter, on which fish depend on to live. If dissolved oxygen shortage found in the pond water fish start gasping and in that cases aeration should be provided immediately, otherwise sever fish mortality may occur. During the study period the dissolved oxygen varied from 4.5 to $7.2 \mathrm{mg} / \mathrm{l}$. More or less similar result was reported by Hossain et al. (1999), they recorded DO values of fish ponds ranged from 3.8 to $6.9 \mathrm{mg} / \mathrm{l}$. Bhuiyan (1970) stated the DO concentration 5.0 to $7.0 \mathrm{mg} / \mathrm{l}$ within the good productive range. Banerjee (1967) and Bhuiyan (1970) reported 5 to $7 \mathrm{mg} / \mathrm{DO}$ content of water is fair or good in respect of productivity and water having DO less than $5 \mathrm{mg} / \mathrm{l}$ to be unproductive. During the present study the values of free Carbon-dioxide were fluctuated between 5.0-8.7 mg/l. Alam et al. (2002) recorded free $\mathrm{CO}_{2}$ (5-13 mg/l) from fish culture ponds in Mymensingh. Suitable range of free $\mathrm{CO}_{2}$ is not more than $12 \mathrm{mg} / \mathrm{l}(\mathrm{DoF} 2015)$. The suitable range of free $\mathrm{CO}_{2}$ for fish culture is less than $10.0 \mathrm{ppm}$ (Boyd, 1990). The concentration of free carbon dioxide was found directly related to the amount and nature of biological activities in the water. The carbon dioxide, $\mathrm{pH}$ and alkalinity are thus directly related with each other (Michael, 1969). During the study period the value of alkalinity ranged from 48.0 - $85.0 \mathrm{mg} / \mathrm{l}$. Alikunhi (1957) reported that total alkalinity more than $100 \mathrm{mg} / \mathrm{l}$ should be presented in high productive water bodies. Rath (2000) stated that calcareous water with alkalinity more than $50 \mathrm{ppm}$ was most productive. He also described the range of alkalinity 0-20 ppm as low productive, 20-40 ppm as medium productive and $40-90 \mathrm{ppm}$ as high productive. On the basis of above author's findings it can be accomplished that the total alkalinity recorded from the present study was within productive range. During the study period, the range of $\mathrm{pH}$ values recorded in the ponds were found to vary between 6.8 to 7.8 , which are more or less similar to Boyd (1990), who stated that the suitable range required for fish culture 6.5 to 9.0. According to Trivedi and Raj (1992) the optimum range of $\mathrm{pH}$ for aquatic life was recorded as $6.8-9.0$. However, the $\mathrm{pH}$ value in alkaline condition in water was supposed to be helpful for proper growth and development of fishes and aquatic organisms (Nikolsky 1963, Jhingran 1991). An acidic $\mathrm{pH}$ reduces the growth rate, metabolic rate and other physiological activities of fish (Swingle 1969).

\section{Conclusion}

The findings of the present experiment showed that inclusion of bivalve in the carp aquaculture enhanced the production of carp and with additional production of bivalve. The results will provide invaluable information of carp-bivalve aquaculture and will provide an important baseline data for the future studies on freshwater bivalve aquaculture. Therefore, further studies need to optimize stocking density and species composition to explore ultimate potential of bivalve aquaculture in the Barind Tract region for boosting up overall aquaculture production in Bangladesh.

\section{Acknowledgements}

We are grateful to Grant (Project ID: LS201677) of Advanced Research in Education (GARE), Bangladesh Bureau of Educational Information \& Statistics (BANBEIS), Ministry of Education, Government of the People's Republic of Bangladesh for financial assistance to conduct this study.

\section{References}

Alam MJ, Kohinoor AHM, Islam MS and Mazid MA (2002). Polyculture of carps using over-wintered fingerlings under different stocking densities. Bangladesh Journal of Fisheries Research, 6(2): 117-124.

Alikunhi KH (1957). Fish culture in India Farm, Bull. No. 20, India Counc. Agric. Res. New Delhi, pp. 144.

Arook T, Rahman MR, Ali MY and Javed, A (2016). Socio-economic condition of plain land tribal people in Bangladesh. Social Sciences, 5(4): 58-63. doi:10.11648/j.ss.2016.05.04.12 
Banerjee SM (1967). Water quality and soil condition of water body in states of India in relation to fish production. India Journal of Fisheries, 14: 115-144.

Bhatnagar A and Devi P (2013). Water Quality Guidelines for the Management of Pond Fish Culture. International Journal of Environmental Science, 3(6): 1980-2009. doi.org/10.6088/ijes.2013030600019.

Bhuiyan BR (1970). Physio-chemical qualities of water of some ancient tanks in Sibsagar, Assam. Environment Health, 12: $129-134$.

Boyd CE (1990). Water quality parameters in pond for culture. Birmingham publishing company, Birmingham, Alabama. pp. 482.

Boyd CE and Tucker CS (1998). Pond Aquaculture, water quality management, Kluwer Academic Publisher London.

Brett JR and Groves TDD (1979). Physiological energetics. In: Fish Physiology, Vol. III, Bioenergetics and Growth, Hoar WS, Randall DJ and Brett JR (eds), New York: Academic Press. pp. 280-352.

Chakraborty S, Ray M and Ray S (2008). Sodium arsenite induced alternation of hemocyte density of Lamellidens marginalis an edible mollusk from India. Clean, 36(2): 195-200.

DoF (2015). National Fish Week 2013, Compendium (in Bengali). Department of Fisheries, Ministry of Fisheries and Livestock, Bangladesh, pp.124-130.

DoF (2017). National Fish Week Compendium (In Bengali). Department of Fisheries, Ministry of Fisheries and Livestock, Bangladesh. 160p.

Haque R (2010). Growth and production performance of carps in different stocking densities of polyculture, MS Thesis, Department of Aquaculture, Bangladesh Agricultural University, Mymensingh, pp. 35.

Hossain MA, Hossain, MA, Haque MA, Mondol MMR and Rashid MHU (2020). Determination of suitable species combination for good aquaculture practice based carp fattening in ponds under drought prone Barind area of Bangladesh. Archives of Agriculture and Environmental Science, 5(2): 114-122.

Hossain MAMR, Amin IMS and Haque MM (1999). Comparative growth performences of riverine and hatchery produced Indian major carps (Catla catla Ham., Labeo rohita Ham., and Cirrhinus mrigala Ham.). Bangladesh Journal of Zoology, 27(1): 65-73.

Jhingran VG (1991). Water quality in ponds for aquaculture.Ala. Agr. Enp. Sta. Auburn Univer. Ala., pp. 462.

Kobir MH, Hossain MR, Hossain MA, Dey SK and Sultana S (2017). Carps polyculture technique in Mohanpur, Rajshahi region of Bangladesh. Asian Australas Journal of Bioscience \& Biotechnology, 2(1): 100-105.

Lakshman MAV, Sukuinaiun KK, Murty DS, Chakraborty PP and Philipose MT (1971). Preliminary observations on intensive fish farming in freshwater ponds by the composite culture of Indian exotic species. Journal of Inland Fisheries Society, India 3: 1-21.

Michael GR (1969). Seasonal trends in physico-chemical factors and plankton of freshwater fish pond and their rules in fish culture. Hydrobiology, 33(1): 144-160.

Mollah MFA and Haque AKM (1978). Studies on monthly variations of plankton in relation to the physico-chemical conditions of water and bottom soil of two ponds. 1- phytoplankton. Bangladesh Journal of Fisheries, 1(1): 29-39.

Nikolsky GV (1963). The ecology of fishes. Academic press, London, pp. 362.

Rahman MM (2006). Qualitative and quantitative study of plankton in relation to some water quality parameters in two beels in Tangaile.Department of aquaculture, Faculty of Fisheries, Bangladesh Agricultural University, Mymensingh 2202, pp. 93.

Rahman MS, Chowdhury Y, Haque AKMA and Haq MS (1982). Limnological studies of four ponds. Bangladesh Journal of Fisheries, 2 (1): 25-35. 
Rath RK (2000). Freshwater aquaculture (second edition) scientific publishers, Jodhpur, India.

Rosenberg DM and Resh VH (1993). Freshwater Biomonitoring and Benthic Macroin vertebrates.Chapmanand Hall, NewYork, NY, pp. 488.

Samad M (2006). The Santals in Bangladesh: Problems, Needs and Development Potentials. Journal of Ethnic Affairs, vol. 2, 2006, pp. 9-13.

Swingle HS (1969). Standardization of chemical analysis for water and pond Mud's. FAO Fish Report, 4(4): 397-421.

Talukder MGS, Hossain MA, Mohsin ABM and Khan RI (2018). Performances of bottom dwelling carps in polyculture ponds under drought prone barind area of Bangladesh. Journal of Aquaculture and Marine Biology, 7(1): 13-20. doi:10.15406/jamb.2018.07.00178.

Talukder MGS, Mohsin ABM, Hossain MA and Khan MRI (2017). Optimization of stocking weight in carp polyculture ponds under drought prone Barind area of Bangladesh. Journal of Fisheries, 5(3): 519-524.

Trivedi PR and Raj G (1992). Water Pollution. Published by Akashdeep Publishing House, New Delhi, pp. 304.

Wahab MA, Ahmed ZF, Islam A and Rahamatullah SM (1995). Meet of introduction of common carps, Cyprinus carpio (L.) on the pond ecology and growth of fish in polyculture. Aquaculture Research, 26: 619-628.

(Manuscript received on 21 March 2021; revised on 20 June 2021) 